\title{
INFLUENCE OF "NovuMedical" EQUIPMENT ON NON-SPECIFIC RESISTANCE OF THE ORGANISM TAKING INTO ACCOUNT ADAPTATION REACTIONS
}

\author{
Irina Shuvalova \\ Department of Health and Rehabilitation \\ V. I. Vernadsky Crimean Federal University, Academician of the Russian Academy of Medical \\ and Technical Sciences \\ Vitaliy Golovan \\ Association of Specialists in devices for recovery at home \\ 36 Cherepanovyh driveway, Moscow, Russia, 125008 \\ Lee Sangkyu \\ CEO NovuMedical Co., Ltd. \\ 112 2gongdan 2-ro, Seobuk-gu, Cheonan-si, Chungcheongnam-do, Korea, $2 F$
}

\begin{abstract}
Studies have shown the effectiveness and perspective of using «NovuMedical» devices for the purpose of primary and secondary prevention of diseases, increasing the personal interest of patients in extending the period of active longevity due to regular recovery at home. The preventive effect of the equipment is not directed against the symptoms of the disease, but to increase the body's resistance. Before treatment, the normal type of adaptive response was detected in $75 \%$ of patients, the workout reaction was noted in $45.4 \%$, the calm activation reaction $-23.2 \%$, the reaction of increased activation in $6.2 \%$ of cases, and the stress response was recorded in $25.2 \%$. After the treatment, the workout reaction was detected in $44.1 \%$ of cases, the calm activation reaction $22.2 \%$, the increased activation zone $-33.3 \%$. The preformed factors used in the apparatuses are a bioregulator in the broad sense of modulating the physiological functions of the body, which makes it possible to "rejuvenate" the sick organism, at least to equalize the biological and passport age, to restore the original potential of sanogenetic reactions. Apparatus for home use can be the basis for the primary population prevention and secondary individual prevention of a wide range of diseases and premature aging.

Keywords: devices for home use, non-specific resistance, adaptation, preservation of health, prevention.
\end{abstract}

\section{Introduction}

Improving existing and developing new ways and methods of prevention diseases is one of the most important problems of medicine. Preventive medicine plays a leading role in preserving the health of a modern person, which is why much attention is paid to it, innovative technologies are being improved and developed [1,2]. Rational prevention is based primarily on increasing mobilization readiness and the effect of the protective and adaptive mechanisms of the human body. As mass preventive measures, methods for enhancing adaptive capacity should be widely used, providing an increase in nonspecific or cross-resistance, which means the body's ability to withstand the effects of adverse external and internal factors by maintaining the functions of individual systems and maintaining dynamic regulated interrelations between them $[3,4]$.

The use of preformed physical factors for the correction of pathological disorders in preventive and restorative treatment, as a rule, stimulates sanogenetic mechanisms of the organism and organ levels, improving tissue and cell levels, which certainly leads to the reverse development of the pathological process and its stabilization $[3,5]$. Physiotherapy preformed factors, as one of the types of complementary medicine, can significantly increase the nonspecific resistance of the organism. Their feature is the ability to directly influence the immune-biological protective properties of the organism, both local and general, thereby increasing its adaptive capacity $[1,6]$. The best physiological preformed methods, for example, exposure to altered gaseous media - aeroionotherapy, ozone therapy, as well as magnetic therapy, bioresonance heat, laser radiation, etc. - have the best efficacy and safety profile $[5,7]$. The introduction of a methodological approach to the re- 
covery process from the standpoint of managing the «Pathogenesis-Sanogenesis» system is urgent, relevant and at the same time very challenging.

Currently, an increasing number of specialists are attracted by the practical use of physical methods in the prevention, treatment, rehabilitation, preservation and strengthening of health, correction of aging syndromes, which is associated with the improvement of the methodology of physiotherapy $[3,5]$. In addition, physical methods of treatment and prophylaxis, in contrast to drug therapy, act more systemically and physiologically, have the ability to influence both directly the pathological process and the general regulatory functions in the whole organism, in addition, they are deprived of many undesirable phenomena, characteristic of drug treatment and prevention $[3,5]$.

Modern preventive medicine offers a set of measures aimed at reducing the risk of the occurrence and development of acquired diseases and their consequences [1]. First and foremost, it is an individual or personalized approach that distinguishes preventive medicine from all others [8,9].

Direction, recovery at home, a prominent representative of which is «NovuMedical», leads to a fundamentally new paradigm of health care, when not only all the social institutions of the state, but also the patients themselves, first of all, the most conscious and educated part of the population, become immediate and active participants in the process of maintaining health [10, 11].

\section{Aim of the work}

The aim of the research is to study the effect of «NovuMedical» equipment on the nonspecific resistance of the organism.

\section{Materials and methods}

The study was conducted on the basis of the Yalta Demonstration Center from 2016 to 2018. It included 320 patients who underwent rehabilitation according to the 5/95 program, where one hour of use of the equipment allows a $95 \%$ improvement in the quality of life.

From the number of the examined there were 216 women and $104 \mathrm{men}$, aged from 38 to 78 years, the average age of patients was $63 \pm 5.6$ years.

All patients had previously undergone outpatient or inpatient examination and treatment and had an established, verified diagnosis. Of the patients examined, many had a certain "bunch" of diseases. So, $65 \%$ had diseases of the cardiovascular system, $70 \%$ had diseases of the musculoskeletal system, $50 \%$ had diseases of the peripheral vessels, $55 \%$ had diseases of the internal organs, $60 \%$ had eye diseases, $30 \%$ had respiratory diseases. Lipid metabolism disorders were detected in $89 \%$, carbohydrate metabolism in $56 \%$, and coagulation disorders were detected in $72 \%$. In the process of using «NovuMedical»equipment and the rehabilitation of such patients with different diseases, $92 \%$ of patients showed positive dynamics during the course of the disease, which suggested some universal effect of the equipment on the body.

For the correction of acquired diseases and their prevention, the devices «TopRelax», «NovuHeat», «NovuEye», «BodyHealth», «MOXI» were used.

«TopRelax» (Korea) is a vibro-massage apparatus for the correction of the spinal column, producing a variety of rhythmic, vibratory tapping, with the ability to turn on infrared heat up to $770 \mathrm{~nm}$. In operation, the magnets in the apparatus create a constant magnetic field of $-72 \mathrm{mT}$ during operation, and tourmaline inserts enrich the impact zones with negative air ions -1000 ions per $\mathrm{cm}^{3} \pm 200$. The received energy radiates heat, local heating is carried out. Infrared energy is able to penetrate the tissues of the body in a wave way, also heating them. Due to the vibratory massage, a targeted system of transmission of mechanical vibrations to the human body is carried out to affect its various organs and systems, due to stimulation of the receptors on the skin surface, muscles, and tendons. Such effects lead to the emergence of electromotive forces, the transformation of the energy of the active factors into the energy of the body cells, the expansion of blood vessels and the acceleration of the movement of blood and other fluids inside the body.

«NovuEye» (Korea) - eye massager, acupressure of the eye orbit points, vibratory massage, infrared heat up to $770 \mathrm{~nm}$, constant magnetic field $-85 \mathrm{mT}$, ionization -1000 ions per $\mathrm{cm}^{3} \pm 200$. 
«NovuHeat» (Korea) - thermal carpet enriched with magnets and tourmaline is designed to correct sleep and deep body warming up to 70 degrees, exposure to infrared heat up to $770 \mathrm{~nm}$, ionization of exposure zones -1000 ions per $\mathrm{cm}^{3} \pm 200$, constant magnetic field $-30 \mathrm{mT}$.

«BodyHealth» (Korea) - the device is designed for the rehabilitation treatment of the vessels of the lower extremities, the active factors are myostimulation, stimulation of the reflex points of the foot and infrared heat, which allows for efficient, completely painless and safe activation of the blood circulation. The pulse duration is $0.5-300 \mathrm{~m} / \mathrm{s}$. The frequency of the pulses $-10-150 \mathrm{~Hz}$. The shape of the pulses is neural-like.

«MOXI» (Korea) - apparatus for acupuncture and to exercise meridians. The device uses preformed physical factors: infrared heat up to $770 \mathrm{~nm}$, with the ability to control the temperature from 40 to 70 degrees, which allows not only to heat the AT, but also to cauterize them. Tourmaline insert to enrich the site of impact with negative air ions -1000 ions per $\mathrm{cm}^{3} \pm 200$, constant magnetic field $-30 \mathrm{mT}$, low-frequency vibration -3 modes $(10-30 \mathrm{~Hz})$, as well as low-energy laser radiation with a wavelength of $630 \mathrm{~nm}$, power $10 \mathrm{mV}$.

The state of the psycho-emotional sphere was assessed by the SAN test. A general non-specific adaptive response was determined, the indicator of which was the Garkavi-Kvakina-Ukolova index [12]. In accordance with this, the ratio of lymphocytes to segmented neutrophils in the leukocyte formula of blood 0.30 and less indicates the presence of stress, $0.31-0.50$, indicates a training reaction, $0.51-0.70$ - a reaction of calm activation, 0.71 and above - increased activation reaction. The survey was conducted before the start of the procedures and after 30 days of preventive treatment.

The biological age of the patients was determined according to the method of Shakhbazov V. G. Heat, ionization, magnetic field, laser radiation affect the energy metabolism of cells and under certain conditions normalize it. In this connection, the method of measuring the electronegativity of cell nuclei (ENN, \%) seems promising. The direction and degree of deviations of the electronegativity index of cell nuclei from the norm before and during the treatment process allow assessment of the patient's energy state [13].

The survey was carried out in the medical laboratory SINEVO, the laboratory is certified according to the international quality management standard ISO 9001: 2000. All results were statistically processed by Student's and Mann Whitney methods taken for small samples using the Statistica 6.0 computer program.

\section{Results of the research}

According to the survey, questioning, interviewing $92.5 \%$ of patients reported improvement in overall health and well-being, improved quality of life in Fig. 1.

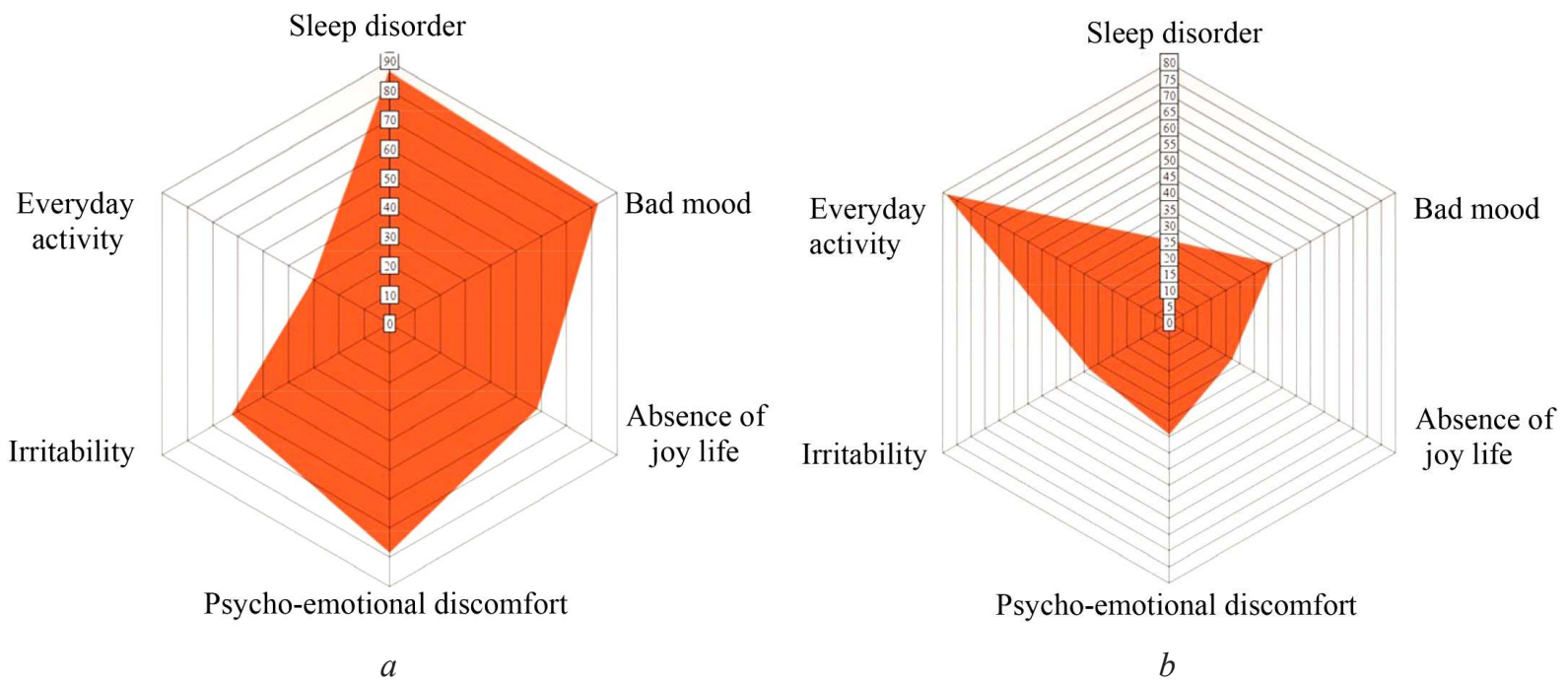

Fig. 1. Dynamics of subjective data: $a$ - before recovery; $b$ - in 3 months 
After a course of prophylactic recovery, a statistically significant $(\mathrm{p}<0.05)$ normalization of well-being indices according to the SAN test was observed with 4.0 (before treatment) and 4.6 points during the treatment process; activity from 3.9 to 4.4 points, mood from 3.9 to 4.7 points.

Before treatment, the normal type of adaptive reactions in the examined patients was detected in $75 \%$ of cases, of which the training response was noted in $45.4 \%$, the calm activation reaction $-23.2 \%$, the increased activation reaction in $6.2 \%$ of cases, and stress response was recorded in $25.2 \%$ of patients. As a result of prophylactic treatment, almost all patients had a normal type of adaptive response, shown in Table 1.

Table 1

Dynamics of adaptation reactions

\begin{tabular}{cccc}
\hline No. & Type of adaptive response & Before treatment (\%) & After treatment (\%) \\
\hline 1 & Workout reaction & 45.4 & 44.1 \\
2 & Quiet activation reaction & 23.2 & 22.2 \\
3 & Reaction of increased activation & 6.2 & 33.3 \\
4 & Stress response & 25.2 & 0.4
\end{tabular}

in Table 2.

The effect of various devices on changes in the lymphocyto-neutrophil index is presented

Table 2

Characteristics of changes in the lymphocyto-neutrophilic index under the influence of various «NovuMedical» devices

\begin{tabular}{ccccccc}
\hline \multirow{2}{*}{$\begin{array}{c}\text { Indicator } \\
\text { Initial data, \% }\end{array}$} & \multicolumn{5}{c}{ As a result of devices use } \\
\cline { 3 - 7 } & & TopRelax & NovuEye & NovuHeat & BodyHealth & MOXI \\
\hline Activation reaction & 29.4 & 60.3 & 56.2 & 61.9 & 57.4 & 61.5 \\
Workout reaction & 45.4 & 39.4 & 43.2 & 37.6 & 42.2 & 38.3 \\
Chronic stress response & 25.2 & 0.3 & 0.6 & 0.5 & 0.4 & 0.2
\end{tabular}

Studies have shown that the response of the subjects to exposure by different devices in terms of the ENN index, \% is similar, but substantially depends on the initial values of the ENN index, \%, shown in Fig. 2.

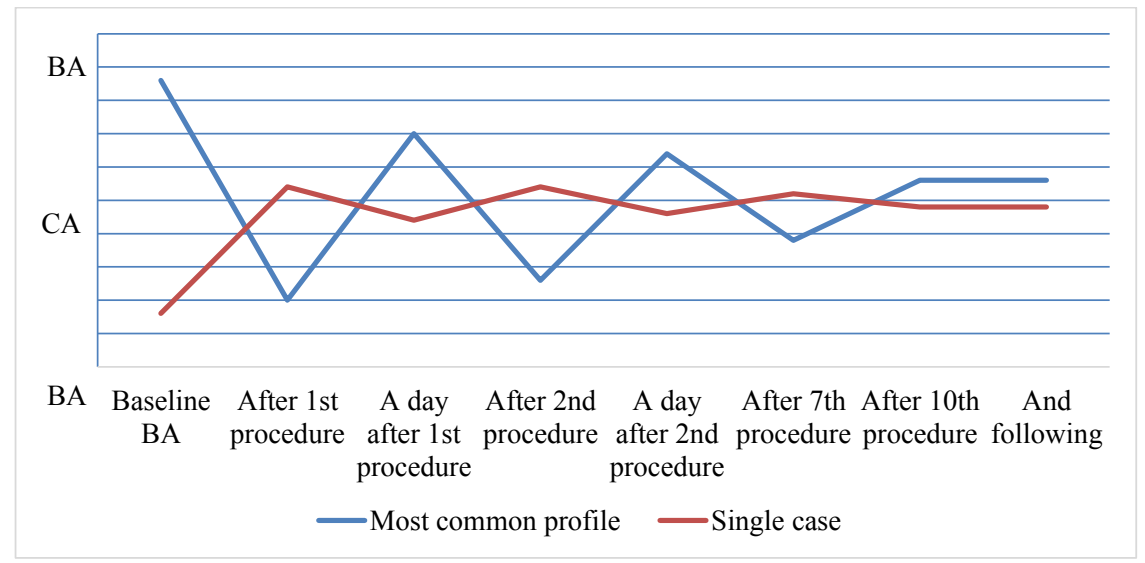

Fig. 2. Averaged profile of reactions of nuclei of the buccal epithelium to the effects of NM devices (by electronegativity (ENN, \%): CA - chronological (passport) age; BA - biological age (by $\%$ of electronegativity of nuclei of the buccal epithelium) 
Excess of biological age over passport data in various age groups of the examined patients is presented in Fig. 3.

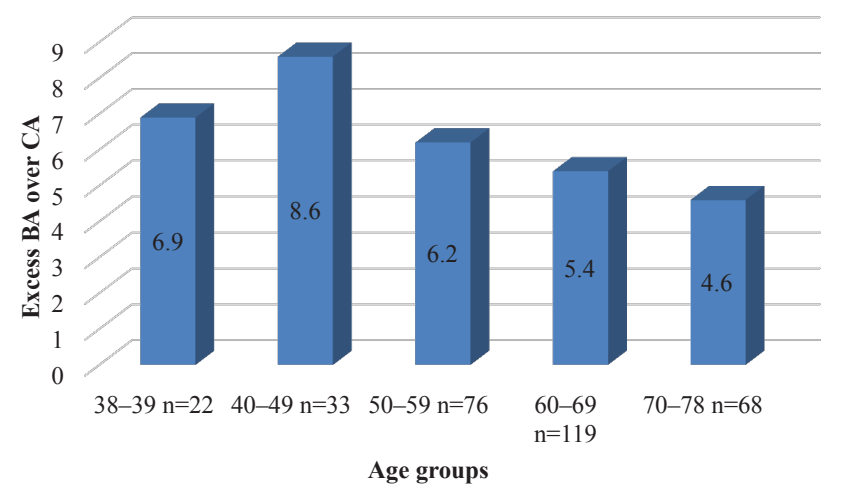

Fig. 3. Excess biological age over passport age in examined patients in various age groups

The study analyzed the dynamics of biochemical parameters, that are shown in Table 3 .

Table 3

Dynamics of biochemical blood parameters

\begin{tabular}{lccc}
\hline \multicolumn{1}{c}{ Indicator } & $\begin{array}{c}\text { The number of patients with } \\
\text { altered indicators }\end{array}$ & Initial data & $\begin{array}{c}\text { Data after a monthly course } \\
\text { of procedures }\end{array}$ \\
\hline 1. Lipid exchange & & $6.2 \pm 0.37 \mathrm{mmol} / \mathrm{l}$ & $5.8 \pm 0.23 \mathrm{mmol} / 1$ \\
- cholesterol & 267 & $0.83 \pm 0.27 \mathrm{mmol} / 1$ & $0.93 \pm 0.12 \mathrm{mmol} / 1$ \\
- high-density lipoprotein & & $0.68 \pm 0.02 \mathrm{mmol} / 1$ & $0.62 \pm 0.25 \mathrm{mmol} / 1$ \\
- low-density lipoprotein & 179 & $0.94 \pm 0.13 \mathrm{mmol} / 1$ & $0.92 \pm 0.22 \mathrm{mmol} / 1$ \\
- triglycerides & & $6.4 \pm 0.51 \mathrm{mmol} / 1$ & $5.6 \pm 0.27 \mathrm{mmol} / 1$ \\
2. Carbohydrate metabolism. & & & $68.6 \pm 0.6$ \\
Blood glucose & & $72.3 \pm 0.8$ & $4.44 \pm 0.12 \mathrm{~g} / 1$ \\
3. Blood coagulation system & 230 & $4.35 \pm 0.15 \mathrm{~g} / 1$ & $89.8 \pm 0.65 \mathrm{~g} / 1$ \\
- plasma tolerance to heparin & & $97.2 \pm 0.78 \mathrm{~g} / 1$ & $5.0 \pm 0.15$ \\
- fibrinogen level & & $5.5 \pm 0.2$ &
\end{tabular}

In order to study the effect of equipment on the state of the cardiovascular system, we analyzed the dynamics of blood pressure and pulse in 33 patients, age group 40-49 years, Table 4.

Table 4

Dynamics of blood pressure and pulse

\begin{tabular}{cccc}
\hline Baseline blood pressure & Baseline pulse & AT after treatment & Pulse after treatment \\
\hline $152 \pm 1.5 / 106 \pm 0.7 \mathrm{~mm} \mathrm{Hg}$ & $91 \pm 3.3$ & $134 \pm 2.4 / 82 \pm 1.8 \mathrm{~mm} \mathrm{Hg}$ & $79 \pm 3.1$
\end{tabular}

\section{Discussion}

Resistance of the organism largely determines the incidence, severity of the disease, the effectiveness of treatment. By causing a targeted, desired adaptive response of the organism at 
a certain level of reactivity, one can approach the management of the resistance of the organism. As a result of prophylactic treatment, almost all patients had a normal type of adaptive response. So, the training reaction was detected in $44.1 \%$ of cases, the calm activation reaction $-22.2 \%$, the increased activation zone $-33.3 \%$, against $6.2 \%$ before the start of treatment, and the stress response was detected only in 1 patient $-0.4 \%$ vs. $25.2 \%$ before treatment. It is during the activation reaction of high levels of reactivity that high functional activity of protective - adaptive mechanisms, good coordination of the activities of various systems, the presence of rapidly recovering functional reserves are noted. The possibility of harmonizing the state of even a sick organism is explained by the fact that the organism, being a self-organizing system, is able to use external signals for self-healing. Similar results were obtained by other researchers [12]. With the development of the reaction of increased activity, optimism, thirst for activity, excellent mood, general recovery, increase in working capacity are noted, which is established in our study. Patients noted improved sleep (92\%), mood (98\%), the emergence of interest and joy of life (87\%), the state of psycho-emotional comfort (96\%), increased stress tolerance ( $86 \%)$, household activity (94\%).

The physical channel of management and implementation of programs for the development and functioning of the human body is very sensitive to the effects of external physical factors $[14,15]$, which we note in our study. This is explained by the fact that the main link of the trigger mechanism of the body's response to an external factor is the change in the cell's electrical status, a group of cells due to changes in the electrical charges of macromolecules, and the endogenous synthesis and release of neurotransmitters depends primarily on the amount of electrical energy and its dissipation mechanism $[16,17]$.

Studies have shown that the response of the subjects to exposure by different devices in terms of the ENN index, \% is similar, but substantially depends on the initial values of the ENN index, \%. This allows us to conclude that all devices have a similar energy effect on the human body, which is manifested in changes in the bioelectric properties of cell nuclei. The equipment has a normalizing effect, and the more the deviation from the norm was in the initial state of the organism, the more significant was its change after exposure. Explaining the versatility of the apparatus, in the treatment and prevention of various diseases, one should be aware of the universality of the cell structure and the disturbance of their energy metabolism caused by various causes, but always the initial causes of the pathological process $[18,19]$.

The study revealed a significant excess of biological age over chronological, at a younger age. Thus, in the subgroup (38-39 years), BA exceeded the CA by 6.9 years, in the subgroup (4049 years), by 8.6 years, while in the subgroup (70-78 years) by 4.6. Significant excess of biological age over chronological, at a younger age, apparently due to the fact that in these age subgroups are more pronounced and significant risk factors. These age subgroups are more exposed to stress and have insufficient adaptation and compensation mechanisms, as evidence of the imbalance and disintegration of the regulatory system. This suggests a high rate of aging in these subgroups and an increase in the risk of developing somatic diseases. A pattern was revealed. The younger (3849 years) and the earlier diagnosed hypercholesterinemia, the greater the difference between CA and BA in the direction of increasing the latter. The older the patient (60-78 years), the hypercholesterinemia has less effect on the difference between CA and BA. This indicates deterioration in the prognosis of the course of the disease in young people, as well as the possibility of increasing the number of developing complications, and the need to proceed with the correction of these changes as soon as possible. Studies have shown that in the process of recovery only a tendency towards the normalization of biochemical indicators has emerged, but for their substantial positive dynamics or normalization, we believe that a longer period of use of equipment for the purpose of rehabilitation is necessary.

During the application of preformed factors used in the apparatus, it is possible to change and improve the general nonspecific adaptive response of the organism and at the same time to selectively regulate the function of organs and systems according to the principle of segmental and vegetative innervation. The improvement of the functional state of the cardiovascular system was revealed. Thus, in the process of recovery, systolic pressure decreased from $152 \pm 1.5 \mathrm{~mm} \mathrm{Hg}$ up to $134 \pm 2.4 \mathrm{~mm} \mathrm{Hg},(\mathrm{p}<0.05)$ and diastolic with $106 \pm 0.7 \mathrm{~mm} \mathrm{Hg}$, to $82 \pm 1.8 \mathrm{~mm} \mathrm{Hg}(\mathrm{p}<0.05)$ Dynam- 
ics was detected in the normalization of the pulse from $91 \pm 1.3$ to $79 \pm 1.1(p<0.05)$. Similar results are noted by other researchers $[20,21]$. These features of the devices used ensure the development of combined specific and nonspecific therapeutic and prophylactic effects.

Our study was certainly limited to the ability to more deeply study the processes occurring in the patient's body, studying the dynamics of the state of capillary circulation, calculating the mathematical expression of the patient's health level, changing the parameters of humoral immunity when using the devices at home can be very informative.

The results showed the effectiveness, relevance and prospects of the use of «NovuMedical» devices for home use, with the aim of primary and secondary prevention of diseases, increasing the personal interest of patients in extending the period of active longevity due to regular recovery at home.

\section{Conclusions}

1. The preventive effect of the apparatus on the body is accompanied by a complex structural-metabolic restructuring at different levels of the biological organization: cellular, organ, systemic, organismal.

2. The preventive effect of the equipment is not directed against the symptoms of the disease, but to increase the body's resistance. The preformed factors used in the apparatuses are a bioregulator in the broad sense of modulating the physiological functions of the body, the neuroendocrine and immune systems, as well as the cellular biochemical activity ensuring the mobilization of sanogenetic mechanisms.

3. The equipment has a normalizing effect at all levels of the organization, from subcellular structures to high levels of body regulation, which allows to "rejuvenate" the sick body, at least to equalize the biological and passport age, to restore the initial potential of sanogenetic reactions, which is the main condition for prevention and treatment patients.

\section{References}

[1] Trofimova, S. V., Trofimov, A. V. (2017). Innovatsionnye tekhnologii preventivnoy meditsiny. Vestnik vosstanovitel'noy meditsiny, 1, 37-40.

[2] Trukhanov, A. I., Chudakov, S. Yu. (2017). Rol' preventivnoy meditsiny v sotsial'noy politike gosudarstva. Vestnik vosstanovitel'noy meditsiny, 1 (77), 8-17.

[3] Bykov, A. T., Chernyshov, A. V., Drozdova, V. M. (2017). Fizicheskie metody profilaktiki, lecheniya i reabilitatsii: proshloe, nastoyashhee i budushhee. Vestnik fizioterapii i kurortologii, 4, 78-82.

[4] Gems, D. (2014). What is an anti-aging treatment? Experimental Gerontology, 58, 14-18. doi: http://doi.org/10.1016/j.exger.2014.07.003

[5] Ponomarenko, G. N. (2009). Innovatsionnye tekhnologii fizioterapii. Voprosy kurortologii, fizioterapii i lechebnoy fizicheskoy kul'tury, 4, 3-8.

[6] Kesava, R. G., Davis, C. H. (Eds.) (2009). Biomedical Application of Low energy Laser. Complementary Therapies in Rehabilitation. Therefore SLACK Incorporated. Publ., 383-398.

[7] David Baxter, G. (2009). Laser Acupuncture: Effectiveness Depends upon Dosage. Acupuncture in Medicine, 27 (3), 92. doi: http://doi.org/10.1136/aim.2009.000794

[8] Dontsov, V. I., Krut'ko, V. N. (2017). Personalizirovannaya korrektsiya sindromov stareniya kak novoe napravlenie preventivnoy meditsiny. Vestnik vosstanovitel'noy meditsiny, 1, 30-36.

[9] Shuvalova, I. N., Kostin, N. F. (2018). Sanogeneticheskie aspekty ozdorovleniya patsientov vertebro- nevrologicheskogo profilya s ispol'zovaniem massazhno- teplovogo oborudovaniya domashnego primeneniya. Vestnik Fizioterapii i kurortologii, 1, 76-79.

[10] Shuvalova, I. N. (2015). Vosstanovlenie adaptatsionnykh vozmozhnostey organizma studentov s ispol'zovaniem zdorov'esokhranyayushhikh apparatov «TopRelax» i «NovuEye». Vestnik sovremennoy nauki, 8, 141-146.

[11] Shuvalova, I. N. (2017). Obosnovanie primeneniya apparata «BodyHealth» v ozdorovitel'noy terapii bol'nykh obliteriruyushhim aterosklerozom sosudov nizhnikh konechnostey. Vestnik fizioterapii i kurortologii, 4, 132-134. 
[12] Garkavi, L. Kh., Kvakina, E. B., Kuzmenko, T. S. (1998). Antistressornye reakcii i aktivacionnaia terapiia. Reakciia aktivacii kak put k zdoroviu cherez processy samoorganizacii. Moscow: «IMEDIS», 656.

[13] Shakhbazov, V. G. (1972). Geterozis - Iavlenie obshchebiologicheskoe. Moscow: Izd. «Znanie» Seriia biologii-1, 32 .

[14] Hotta, H., Uchida, S. (2010). Aging of the autonomic nervous system and possible improvements in autonomic activity using somatic afferent stimulation. Geriatrics \& Gerontology International, 10, 127-136. doi: http://doi.org/10.1111/j.1447-0594.2010.00592.x

[15] Vanyshin, B. F., Khavinson, V. Kh.; Doerfler, W., Bohm, P. (Eds.) (2016). Short Biologically Active Peptides as Epigenetic Modulators of Gene Activity. Epigenetics - A Different Way of Looking at Genetics. Springer International Publishing Switzerland, 69-90.

[16] Knappe, V., Frank, F., Rohde, E. (2004). Principles of Lasers and Biophotonic Effects. Photomedicine and Laser Surgery, 22 (5), 411-417. doi: http://doi.org/10.1089/1549541042555668

[17] Wang, D. (2008). Reticular formation and spinal cord injury. Spinal Cord, 47 (3), 204-212. doi: http://doi.org/10.1038/sc.2008.105

[18] Yamamoto, N. (2008). Molecular mechanisms of thalamocortical circuit formation. Brain Nerve, 60 (4), 355-375.

[19] Yin, C. S., Park, H. J., Chung, J.-H., Lee, H.-J., Lee, B.-C. (2009). Genome-Wide Association Study of the Four-Constitution Medicine. The Journal of Alternative and Complementary Medicine, 15 (12), 1327-1333. doi: http://doi.org/10.1089/acm.2009.0205

[20] Zhao, J. S. (2007). Modern expression of classical acupuncture and moxibustion theories. Zhongguo Zhen Jiu, 27 (11), 851-855.

[21] Bing, Z., Hongcai, W. (Eds.) (2010). Basic Theories of Traditional Chinese Medicine. Singing Dragon, 192 